\title{
Arkistotoimen organisointi Suomen senaatissa kaksi vuosisataa sitten
}

\author{
Eljas Orrman \\ Professori, ent. arkistoneuvos \\ eljas.orrman@pp1.inet.fi
}

The paper deals with the organization of records and archives management in the middle of 1810 at the Senate, i. e. the supreme administrative board of the Grand Duchy of Finland, belonging to the Russian Empire. Also the reasons why the creation of the position of an archivist at the Senate was proposed by the Senate to the EmperorGrand Duke Alexander I are dealt with. Likewise the administrative process resulting in the appointment of the first archivist is described. The new position of archivist at the Senate formed the embryo of the National Archives of Finland in our days. The international, especially Swedish and Russian background, to the establishment of this position is also described. It becomes evident why the new position got the title "archivist" (in Swedish: arkivarie), not "actuary" (in Swedish: aktuarie). In the Russian administration an archivist was responsible for the preservation of noncurrent and semi-current records but in the Swedish administration this title was very seldom used in the beginning of the 19th century. There actuaries were in charge of the preservation of noncurrent and semi-current records.

Asiasanat: arkistotoimi; asiakirjahallinto; hallintohistoria; Suomen senaatti; 180o-luku; 170o-luku

Kun Suomi Haminan rauhansopimuksen seurauksena 1809 joutui Venäjän keisarikunnan yhteyteen ja sai autonomisen suuriruhtinaskunnan aseman, uudelle suuriruhtinaskunnalle perustettiin oma keskushallinto-organisaatio, Suomen Suuriruhtinaskunnan Hallituskonselji. Sen nimi muutettiin 1816 Keisarilliseksi Suomen senaatiksi. Hallituskonseljiin alkoi kertyä sen virkatoimintaan liittyviä asiakirjoja, ja sinne ryhdyttiin pian muualtakin siirtämään asiakirjoja. Hallituskonseljissa ja sitten Artikkeli on lisensoitu Creative Commons Nimeä-EiKaupallinen-JaaSamoin 4.o Kansainvälinen -lisenssillä 
Senaatissa jouduttiin kiinnittämään huomioita sen haltuun kertyneiden asiakirjojen hoitoon, jotta virkatoiminnassa tarvittavat asiakirjat olisivat olleet käytettävissä niitä tarvittaessa.

Uusien hallinto-organisaatioiden rakenteet ja toimintamuodot ovat historian saatossa pohjautuneet ja pohjautuvat vaihtelevassa määrin edelleenkin vanhempiin esikuviin. Siten organisaatioihin kuuluvien alayksiköiden kuten osastojen ja toimistojen nimitykset sekä myös virkamiesten nimikkeet lainataan yleisesti naapurimaista, usein sellaisista valtioista, joiden hallintokoneistolla on ulkomailla hyvä maine. Siten Venäjällä keskushallinto ja aluehallinto järjestettiin Pietari Suuren aikana 170o-luvun alussa ruotsalaisia esikuvia noudattaen. Ei myöskään ole aivan epätavallista, että valloittajat ovat tuoneet valloittamilleen alueille omia hallintorakenteitaan sekä oman hallintoterminologiansa. Tällaiset tekijät vaikuttivat myös Suomessa, kun maamme Haminan rauhansopimuksen seurauksena 1809 joutui Venäjän keisarikunnan yhteyteen ja sai autonomisen suuriruhtinaskunnan aseman. Hallituskonseljin/Senaatin organisoinnissa vaikuttaneita esikuvia on tutkittu laajasti. Yleensä on kuitenkin pitäydytty kokonaisorganisaation tasolla, eikä sanottavassa määrin ole kiinnitetty huomiota siihen, mistä vaikutteita on haettu ja saatu Senaatin organisaation alimmilla tasoilla. ${ }^{1}$

Hallituskonseljissa ja sitten Senaatissa jouduttiin kiinnittämään huomioita sen haltuun kertyneiden asiakirjojen hoitoon liittyviin ongelmiin, jotta virkatoiminnassa tarvittavat asiakirjat olisivat olleet käytettävissä niitä tarvittaessa. Kuten kaikissa laajemmissa virasto-organisaatioissa, suuriruhtinaskunnan keskushallinto-organisaatiossa oltiin muutaman vuoden kuluttua sen tosiasian edessä, että ilman järjestettyä ja riittävästi resursoitua asiakirjahallintoa ja arkistotointa, ei senaatin virkatoimintaa eikä siihen liittyvää tietopalvelua voitu hoitaa. - Asiakirjahallinto ja arkistotoimi ovat moderneja arkistoalan termejä, jotka tarkoittavat eri vaiheita organisaatioissa käsiteltävien asiakirjojen elinkaaressa. Näitä termejä käyttäen on mahdollista luonnehtia eri-ikäisten asiakirjojen toisistaan poikkeavia käsittelyvaiheita myös vanhemmissa virasto-organisaatioissa. Näille termeille on esitetty muotoilultaan ja myös sisällöltään toisistaan poikkeavia määritelmiä. Asiakirjahallinnolla tarkoitetaan asiakirjojen käsittelyä viranomaisten jokapäiväisessä hallintotoiminnassa, kuten $\mathrm{mm}$. asiakirjojen diariointia ja aktinmuodostusta, sekä tämän toiminnan organisointia organisaation ajankohtaisia tarpeita silmällä pitäen. Arkistotoimen tehtävänä on puolestaan varmistaa asiakirjojen käytettävyys ja säilyminen, huolehtia

$1 \quad$ Esim. K.W. Rauhala, Suomen keskushallinnon järjestäminen vuosina 1808-1817 I, Helsinki 1910, s. 210-231; idem, Keisarillinen Suomen Senaatti 1809-1909 I, Helsinki 1915, s. 1-49; Markku Tyynilä, Senaatti, Helsinki 1992, s. 11-40; Osmo Jussila, Suomen suuriruhtinaskunta, Helsinki 2004, s. 81-113. 
asiakirjoihin liittyvästä tietopalvelusta, määritellä asiakirjojen säilytysarvo ja hävittää tarpeeton aineisto. ${ }^{2}$ Nämä termit eivät kuitenkaan ole sisällöltään toisensa poissulkevia käsitteitä, vaan asiakirjojen käsittelyyn liittyviä tehtäviä liitetään jossain määrin vaihtelevasti sekä asiakirjahallintoon että arkistotoimeen.

Tähänastisessa hallintohistoriallisessa tutkimuksessa on tuotu esille peruspiirteet siitä, miten Hallituskonseljin/Senaatin arkistoimi järjestettiin, mutta tähän liittyviä kysymyksiä ei ole tarkasteltu laajempaa kansainvälistä taustaa vasten. Ei myöskään ole selvitetty, millainen organisatorinen asema arkistotoimella oli suuriruhtinaskunnan keskushallinnossa autonomian ajan alkuvuosina ja millainen vaikutus ruotsalaisilla ja venäläisillä esikuvilla oli, kun arkistotoimen hoito järjestettiin Senaatissa. Kun arkistolaitoksen organisoinnin alun maassamme voidaan katsoa ajoittuvan vuosiin 1816-1817, jolloin Senaattiin perustettiin arkistonhoitajan virka, ja kun vuosina 2016-2017 sen vuoksi juhlistetaan Kansallisarkiston 200-vuotista olemassaoloa, on perusteltua tarkastella lähemmin sitä ympäristöä ja niitä olosuhteita, joissa maamme arkistolaitos sai alkunsa. Samalla on syytä selvittää yksityiskohtaisesti kaikki vaiheet siinä hallintoprosessissa, jonka seurauksena arkistotoimen hoito Senaatissa saatiin vakinaistettua.

$\mathrm{Ne}$, jotka uuden suuriruhtinaskunnan Hallituskonseljissa organisoivat arkistotoimintaa, tunsivat epäilemättä ne käytännöt, joilla arkistotoimen hoitaminen hallintoviranomaisissa oli järjestetty Ruotsissa ja Venäjällä. Kun Vanha Suomi 1812 liitettiin takaisin Suomen yhteyteen, välittyi suuriruhtinaskunnan keskushallintoon tietoa Vanhan Suomen oloista, joten tietämystä venäläisestä hallinnosta oli saatavilla. Myös yleiseurooppalaiset periaatteet, jotka säätelivät sitä, miten asiakirja-aineistojen kanssa tuli menetellä sodissa ja rauhanneuvotteluissa, olivat epäilemättä maamme johtavien virkamiespiirien tiedossa. Tietämys siitä, miten asiakirjahallinto ja arkistotoimi oli organisoitu Venäjällä sekä millaisia arkistoja koskevat käytännöt olivat siellä, on mitä ilmeisimmin vaikuttanut tapaan, jolla arkistotoimen hoito uudessa suuriruhtinaskunnassa järjestettiin. Sen vuoksi tässä esityksessä Suomen arkistolaitoksen perustamisvaiheita 1810 -luvulla on pyritty tarkastelemaan myös kansainvälisessä kontekstissa.

\section{Asiakirja-aineistot huomion ja huolenpidon kohteena uuden ajan alkupuolella valtioidenvälisissä suhteissa}

Euroopan valtioissa oli 1800 -luvun alkuun mennessä muotoutunut yhteisiä käsityksiä asiakirja-aineistojen arvosta ja merkityksestä sekä siitä, miten niiden hoito 
oli tarkoituksenmukaista järjestää. Arkistoaineistojen arvo poliittisen ja hallinnollisen vallankäytön välineenä tiedostettiin kaikkialla. Tämän vuoksi näiden asiakirjojen turvaamiseen kiinnitettiin suurta huomiota ja pyrittiin varmistamaan, että ulkopuoliset eivät päässeet käyttämään niitä. Arkistoaineistojen omistamiseen liittyi uuden ajan alkupuolella myös suurta symbolista hohtoa ja niistä muodostui monesti poliittisten riitojen ja arvovaltakiistojen kohteita. ${ }^{3}$

Sodissa vihollisvaltioiden arkistoaineistot pyrittiin säännönmukaisesti ryöstämään ja saamaan omaan haltuun. Erityisen haluttuja, suorastaan himoittuja olivat vihollisen alueita esittävät kartta-aineistot. Rauhansopimuksissa aina 1500-luvulta lähtien arkistonpalautuksiin ja arkistonluovutuksiin kiinnitettiin suurta huomiota, ja ne jotka rauhanehtoja hierottaessa unohtivat tällaiset kysymykset, joutuivat vaikeuksiin. Yleiseksi periaatteeksi muodostui, että rauhansopimuksiin kirjattiin tarkasti, miten tuli menetellä luovutettavilla alueilla sijainneiden asiakirjojen ja arkistoaineistojen kanssa. Tällaisia määräyksiä sisältyi mm. Altranstädtin rauhansopimukseen 1706, jonka Ruotsi ja Puola tekivät Saksin vaaliruhtinaskunnan kanssa, sekä Utrechtin rauhansopimukseen 1713, jolla Espanjan perimyssota saatettiin suurin piirtein päätökseen. ${ }^{4}$

\section{Asiakirjahallinnon ja arkistotoimen organisointi Ruotsissa ja Venäjällä 180o-luvun alussa}

Ruotsissa toimi $1800-$ luvun alussa ylimmän valtionhallinnon asiakirjoja varten $1600-$ luvun alussa perustettu Valtionarkisto (Riksarkivet). Organisatorisesti se oli Kuninkaalliseen kanslian (Kunglig Majestäts Kansli) (Kansliakollegion) yksikkö, ja sen tehtävänä oli säilyttää Kuninkaalliseen kansliaan kertyneet, pysyvästi säilytettävät asiakirjat, jollaisia arkistossa oli aina keskiajalta lähtien. Valtionarkisto toimi kuitenkin ensi sijassa Kuninkaallisen kanslian virka-arkistona. Sinne siirrettiin säännönmukaisesti kansliassa käsiteltyjen asioiden asiakirjat muutaman vuoden kuluttua käsittelyn päättymisestä, ja se hoiti myös kanslian asiakirjoihin liittyvän tietopalvelun. Muut keskushallinnon yksiköt eivät sen sijaan siirtäneet asiakirjojaan Valtionarkistoon ennen kuin vasta 1800 -luvun jälkipuoliskolta lähtien. ${ }^{5}$

Ruotsalaisessa hallintokäytännössä kameraalihallinnon eli valtion taloushallinnon asiakirjojen käsittely ja pysyvä säilytys hoidettiin täysin erillään muun siviilihallinnon arkistojen (arkistofondien) säilytyksestä. Samaan aikaan kun Valtionarkisto organisoitiin Kuninkaalliseen kansliaan, muodostettiin Kamariin (Kamarikolle-

3 Markus Friedrich, Die Geburt des Archivs. Eine Wissensgeschichte, München 2013, s. 210-211.

4 Friedrich, Die Geburt des Archivs, s. 217-220.

5 Staffan Smedberg, 'Sverige', Det globala minnet. Nedslag $i$ den internationella arkivhistorien, Skrifter utgivna av Riksarkivet 34, Västerås 2012, s. 236-237. 
gioon) Valtionarkistoa vastaava yksikkö, Kamariarkisto (Kammararkivet) huolehtimaan Kamarin pysyvästi säilytettävien asiakirjojen säilyttämisestä; Kamariarkisto oli toiminnassa aina 1900 -luvulle saakka. ${ }^{6}$

Kaikissa eurooppalaisissa valtioissa puolustushallinnon ja joukko-osastojen asiakirja-aineistot säilytettiin 1700-luvun lopulla visusti puolustushallinnon omassa valvonnassa. Eräisiin maihin perustettiin jo 1700-luvulla erillisiä arkistoinstituutioita näiden arkistoaineistojen säilytystä varten. Usein nykyisten sota-arkistojen juuret ovatkin löydettävissä sotilaskarttojen valtakunnallisesta säilytysyksiköstä. Tällaisen arkistoinstituution Ruotsi sai vasta 1805, kun Kenttämittausosaston (Fältmätningskåren) yhteyteen perustettiin Kuninkaallinen sota-arkisto (Konungens krigsarkiv) huolehtimaan tämän sotilaskartoitustoiminnasta vastaavan laitoksen karttaaineistoista. ${ }^{7}$

Arkistotoimintaa muissa ruotsalaisissa keskusvirastoissa 1600 - ja 1700-luvuilla voidaan lähinnä luonnehtia virkatoimintaa tukevaksi asiakirjahallinnoksi, ilman että virastoihin olisi perustettu tai muodostunut selviä tämän alan toimintayksiköitä. Keskusvirastoissa oli kyllä asiakirjahallinnon tehtäviin erikoistuneita virkamiehinä, jotka oli sijoitettu virastojen kanslioihin. Keskushallinnon ulkopuolella tällaisia virkamiehiä näyttää olleen ainoastaan hovioikeuksissa. Sen sijaan Ruotsin ja Suomen lääninhallituksissa ei vielä 1800 -luvun alkuvuosikymmeninä ollut asiakirjahallinnon ja arkistotoimen tehtäviin erikoistunutta virkamiestä. Tukholman maistraatissa oli kuitenkin 1700-luvulta lähtien itsenäisenä organisaatioyksikkönä kaupunginarkisto (stads-archivum) ${ }^{8}$

Termiä arkisto ( $\operatorname{archiv}(u m))$ käytettiin Ruotsin valtionhallinnossa 1700-luvun jälkipuoliskolla ilmeisesti ainoastaan kahdesta edellä mainitusta arkistoinstituutiosta sekä pääkaupungin maistraatin arkistosta. Termiä arkisto on myös käytetty, joskin ilmeisesti säästeliäästi, asiakirjoista koostuvista kokonaisuuksista, aidoista arkistofondeista tai asiakirjoja sisältävistä kokoelmista. ${ }^{9}$ Sen sijaan virkanimike arkistonhoitaja (archivarie, archivarius) oli Ruotsissa harvinainen 180o-luvun alkupuolelle saakka ja yleistyi vasta $1800-l u v u n$ jälkipuoliskolla. Valtionarkiston johdossa oli aina vuoteen 1835 saakka arkistosihteeri (arkivsekreterare) muun virkamiehistön koostuessa aktuaarista ja parista kanslistista. Kamariarkiston johtajana

Kammararkivet, Riksarkivets beståndsöversikt 4, Skrifter utgivna av Svenska Riksarkivet 8:4, Stockholm 1995, s. 27, 389.

7 Smedberg, 'Sverige', s. 241; Erik Norberg, 'Foreword', Guide to Military Archives, Meddelanden från Krigsarkivet XIII, s.l. 1989, s. 1-2; sama, "'Att avfatta krigsteatern”. Krigsarkivet 18051873, Krigsarkivet 200 år, Årsbok för Riksarkivet och Landsarkiven 2005, Västerås 2005, s. 11.

8 Sveriges Krigs- och Civil-Calender 1808; Stockholms Stads-Calender 1790, 1808.

9 Smedberg, 'Sverige', s. 236. 
puolestaan oli tarkastaja (inspektor), eikä sielläkään ollut palveluksessa arkistonhoitajia, ja Tukholman kaupunginarkiston johtajana oli aktuaari. Henkilökunta Sotaarkistossa koostui sotilashenkilöistä, ja johtajaa kutsuttiin komentavaksi upseeriksi (commenderande officerare). Virkanimike arkistonhoitaja näyttää kuitenkin 1800luvun alusta lähtien alkaneen saada jalansijaa Ruotsin valtionhallinnossa. Siten vuosisadan alussa Götan hovioikeudessa oli kirjaajan ja aktuaarin lisäksi arkistonhoitaja, ja Sotakollegion presidenttiosaston presidenttikansliaan perustettiin 1805 arkistonhoitajan virka aiemman aktuaarin viran sijaan. ${ }^{10}$

Asiakirjahallinnosta ja arkistotoimesta vastaavien virkamiesten yleisimpänä virkanimikkeenä keskusvirastoissa oli 18oo-luvun alussa aktuaari (actuarie, actuarius), joka virastoissa yleensä oli sijoitettuna kansliaan; usein aktuaari toimi myös kirjaajana. Kaikkien hovioikeuksien virkakuntaan, myös Suomessa, kuului aktuaari. ${ }^{11}$

Pietari Suuri uudisti Venäjän siviili- ja sotilashallinnon 1710-luvulla. Esikuvat haettiin suurimmaksi osaksi Ruotsista, jonka virastorakenne virastojen nimiä ja virkanimikkeitä myöten suurelta osin kopioitiin suoraan sieltä. Vaikutteita saatiin kuitenkin myös muista maista kuten saksalaisista valtioista. Pietari Suuren luoma virasto-organisaatio ja asiankäsittelykäytännöt vahvistettiin 1720 keskushallintoa varten annetussa yleisessä ohjesäännössä (general'nyj reglament), mutta se toimi pitkälti ohjeena myös aluehallinnolle. Tämä ohjesääntö sääteli monella tavoin hallinnon toimintamuotoja aina keisarikunnan kukistumiseen saakka, vaikka hallinnon virastorakenteessa tapahtui useitakin muutoksia. ${ }^{12}$

Ruotsin Venäjälle Uudenkaupungin rauhassa 1721 sekä Turun rauhassa 1743 luovuttamilla alueilla, Vanhassa Suomessa, eli Viipurin, vuodesta 1802 lähtien Suomen kuvernementissa, säilyi vanha ruotsalainen hallintokäytäntö ohjesääntöineen lähes sellaisenaan aina vuoteen 1812 saakka. Silloin Vanha Suomi yhdistettiin Suomen suuriruhtinaskuntaan. Poikkeuksen muodosti ajanjakso 1784-1797, jolloin koko valtakuntaa koskeva käskynhaltijakuntaorganisaatio venäläisine virastoineen ja hallintokäytäntöineen oli voimassa myös Vanhassa Suomessa. Vaikka tämä hallintoorganisaatio kumottiin 1797, siitä säilyi Vanhan Suomen hallinnossa eräitä aineksia, $\mathrm{mm}$. asiakirjahallinnon ja arkistotoimen osalta. ${ }^{13}$

Venäläisen asiakirjahallinnon ja arkistotoimen organisointi poikkesi selvästi

Sveriges Krigs- och Civil-Calender 1808, s. 6; Stockholms Stads-Calender 1808, s. 7; Birger Steckzén, Krigskollegii historia II-III, Stockholm 1937, s. 479.

Esim. Sveriges Krigs- och Civil-Calender 1808; Stockholms Stads-Calender 1808. Claes Peterson, Peter the Great's Administrative and Judicial Reforms. Swedish Antecedents and the Process of Reception, Rättshistoriskt bibliotek 29, Stockholm 1979.

Jyrki Paaskoski, 'Vanhan Suomen hallintohistoria', Vanhan Suomen arkistot, Arkistolaitoksen yleisluettelo VI, Porvoo 2012, s. 79-83, 111-118; Eljas Orrman, 'Huomioita Vanhan Suomen virastojen asiakirjahallinnosta' (julkaisematon artikkeli). 
vastaavista ruotsalaisista toiminnoista. Pietari Suuren uudistusten myötä perustettiin kaikkia keskusvirastoja, kollegioita, varten erityinen hallinnollisten asiakirjojen yhteisarkisto sekä toinen itsenäinen yhteisarkisto vero- ja taloushallinnon eli kameraalihallinnon asiakirjoja varten. Näihin keskusarkistoihin kollegioiden tuli siirtää loppuun käsiteltyjen asioiden asiakirjat kolmen vuoden kuluttua käsittelyn päättymisestä, ja sama sääntö näyttää koskeneen myös muita virastoja, joissa oli arkistoyksikkö tai arkistotoiminto. Molemmissa edellä mainituissa kollegioiden yhteisarkistoissa oli arkistonhoitajan (arhivarius) nimikkeellä olevia virkamiehiä. Arkistonhoitajan virkanimike yleistyi 1700-luvun kuluessa myös muissa keskushallinnon virastoissa sekä aluehallinnossa. Mainitut yhteisarkistot hoitivat siis sekä asiakirjahallinnon että arkistotoimen tehtäviä. Asiakirjahallinnon tehtävät kuuluivat venäläisissä kollegioissa Pietari Suuren yleisen ohjesäännön mukaan ensisijaisesti kirjaajan (registrator) sekä aktuaarin (aktuarius) nimikkeillä oleville alemmille virkamiehille, joiden molempien tehtäväkentässä kirjeenvaihdon kirjaaminen oli keskeisellä sijalla. Aktuaarin tehtävät sulautuivat kirjaajan tehtäviin ja virkanimike hävisi Ve-

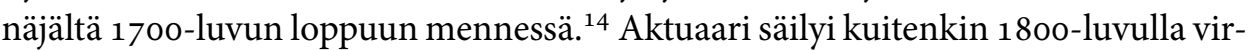
kanimikkeenä imperiumin läntisillä reuna-alueilla, kuten Baltiassa ja Suomessa.

Kuvernementinhallinnon kansliahenkilökuntaan Venäjän käskynhaltijahallintoorganisaatiossa kuului sekä kirjaajia että arkistonhoitajia. Tilanne oli samanlainen Vanhassa Suomessa, jossa uuteen organisaatioon siirryttiin 1784. Viipurin kameraalihovissa, käskynhaltijahallinnon suurimmassa ja organisatorisesti eriytyneimmässä virastossa, joka hoiti vero- ja taloushallintoa, arkistonhoidosta vastasi arkistonhoitaja, joka oli välittömästi virastopäällikön valvonnan alainen.

\section{Arkistotoimen organisoiminen Senaatissa}

Aleksanteri I vahvisti Suomen hallituskonseljille ohjesäännön elokuun 18 päivänä 1809, noin kuukausi ennen Haminassa syyskuun 17 päivänä solmittua rauhansopimusta. ${ }^{15}$ Tässä ohjesäännössä oli myös senaatin arkistonhoito otettu huomioon. Senaatin talousosastossa oli ohjesäännön mukaan esittelevä toimitussihteeri, jonka virkanimike muuttui pian yleiseksi esittelijäsihteeriksi. Tämän korkean virkamiehen tehtävänä oli hoitaa talousosaston toimituskuntien yhteisiä kokouksia. Hänen

14 Gosudarstvennost' Rossii. Slovarj'- Spravočnik 5:1, Moskva 2005, s. 23, 26, 5:2, s. 286. - Ammattinimikkeellä "aktuaari" (venäjäksi myös aktuarij) oli myös muita sisältöjä, mm. vakuutusalalla ja Venäjällä 180o-luvulla tuomioistuinlaitoksessa (pöytäkirjanpitäjä).

15 Aleksanteri I:lle 13/25.11.1816 esitelty ja hänen hyväksymänsä ja allekirjoituksellaan varustamansa esittelynootti, joka koski arkistonhoitajan viran perustamista Suomen senaattiin. http://dx.doi.org/10.6084/m9.figshare.5151688 
työtehtävänsä painottuivat kuitenkin pian senaatin molempien osastojen yhteistunnoissa eli plenumissa käsiteltävien asioiden hoitamiseen. Hallituskonseljin ohjesäännön mukaan yleisen esittelijäsihteerin tehtäviin kuului johtaa senaatin arkistoja (denne förestår archiverne). Muita suoranaisesti arkistoja ja arkistotointa koskevia määräyksiä ohjesääntöön ei sisältynyt, sen sijaan siinä oli asiakirjahallinnon järjestämistä koskevia kohtia. Senaatin talousosastossa käsiteltäviin asioihin liittyvien asiakirjojen käsittely eli asiakirjahallinto kuului ohjesäännön mukaan kansliatoimituskunnan tehtäviin. Tässä toimituskunnassa, joka tehtäviensä puolesta vastasi talousosaston kansliaa, rekisteröitiin talousosastoon saapuneet kirjeet ja asiakirjat ja jaettiin ne valmistelua varten eri toimituskunnille. Talousosaston päätökset antoi esittelevä toimituskunta, mutta niiden lähettäminen kuului kansliatoimituskunnan tehtäviin. Korkeimpana oikeutena toiminut Senaatin oikeusosasto hoiti itse asiakirjahallintonsa. ${ }^{16}$

Haminan rauhansopimuksen 12. artiklan mukaan Ruotsi velvoitettiin luovuttamaan Venäjälle asiakirjat ja arkistot, jotka koskivat Venäjän keisarikuntaan liitettäviä alueita. Tällaisia asiakirjoja olivat omistusasiakirjat ja arkistot sekä muut niin hyvin yleiset kuin yksityiset asiakirjat, linnoitusten ja muiden paikkakuntien asemakaavat ja kartat, samoin kuin maanmittausta koskevat kartat ja asiakirjat. Luovutettavien asiakirjojen vastaanottamista ja noutamista varten asetettiin suomalaisista virkamiehistä koostuva komissio, jolle, kuten odottaa sopiikin, ei kuulunut sotilaskarttojen vastaanottaminen. ${ }^{17}$

Haminan rauhansopimuksen määräykset, joiden perusteella sodassa tappion kärsinyt Ruotsi joutui luovuttamaan menettämiään alueita koskevia asiakirjoja Venäjälle, vastasivat kansainvälistä käytäntöä. Samanlaisia määräyksiä sisältyi myös Uudessakaupungissa 1721 ja Turussa 1743 solmittuihin rauhansopimuksiin. Venäjällä Hallitseva senaatti asetti 1725 erityisen komission, jonka tehtävänä oli valita ja vastaanottaa Baltian alueita, Inkerinmaata sekä Karjalaa ja Viipurin piiriä koskevia asiakirjoja ja arkistoaineistoja. Näyttää kuitenkin siltä, että komissiolle ei luovutettu lainkaan Karjalaa (Viipurin provinssia) koskevia asiakirjoja. Turun rauhansopimuksen nojalla Venäjä ei ilmeisestikään onnistunut saamaan Ruotsilta sanottavassakaan määrin Suomesta luovutettuja alueita koskevia asiakirjoja. Sekä Uudenkaupungin että Turun rauhansopimuksiin sisältyi myös määräys, jonka mukaan Ve-

Finlands allmänna författningar I, Åbo 1821, s. 23-34; Valtionarkiston yleisluettelo II, Helsinki 1966, s. 58-59, 73; Martti Kerkkonen, Suomen arkistolaitos Haminan rauhasta maan itsenäistymiseen, Helsinki 1988, s. 12-13. Ruotsin ja Suomen kesken Haminan rauhan jälkeen', Historiallinen Aikakauskirja 1973, s. 518; Finlands allmänna författningar I, s. 46. 
näjän tuli palauttaa Ruotsille asiakirjat, jotka venäläiset olivat miehityksen aikana vieneet pois ja jotka koskivat Ruotsille jääviä suomalaisia alueita. ${ }^{18}$

Ruotsin viranomaisten Haminan rauhansopimuksen perusteella 1810-1812 suuriruhtinaskunnan viranomaisille luovuttamat asiakirjat sijoitettiin Hallituskonseljin tiloihin Turussa. Poikkeuksen muodostivat kuitenkin sotilaskartat. Hallituskonseljissa asiakirjat inventoi yleinen esittelijäsihteeri, vapaaherra Axel Gustaf Mellin. ${ }^{19}$ Sinne alkoi autonomian ajan ensimmäisinä vuosina kertyä myös muita arkistoaineistoja. Sen tiloihin koottiin 1810 Suomessa toimineiden, lakkautettujen joukko-ostojen arkistoaineistot. ${ }^{20}$ Näitä asiakirjakokonaisuuksia sekä Hallituskonseljin viranhoidon tuottamaa, jatkuvasti kasvavaa virka-arkistoa alettiin kutsua Suomen yleiseksi arkistoksi (Finlands allmänna arkiv). Hallituskonselji käsitteli autonomian ajan ensimmäisinä vuosina Ruotsista luovutettuja asiakirja-aineistoja koskevat asiat mutta myös muita arkistokysymyksiä. Nämä asiat käsiteltiin mahdollisimman korkealla tasolla, senaatin molempien osastojen yhteisistunnossa, plenumis$\mathrm{sa.}^{21}$

\section{Arkistonhoitajan viran perustaminen Senaattiin}

Vuonna 1816, Hallituskonseljin nimen vaihduttua Senaatiksi, kävi ilmeiseksi, että Senaattiin tarvittiin virkamies hoitamaan sekä arkistotoimen että eräitä asiakirjahallinnon tehtäviä. Kesällä 1816 käynnistyi prosessi arkistonhoitajan viran saamiseksi Senaattiin. Asian otti esille Senaatin talousosastossa maaherra Robert Wilhelm De Geer heinäkuun 30 päivänä. Hän totesi, että Senaattiin tarvittaisiin henkilö, jonka tulisi järjestää Senaatin yleisessä arkistossa säilytetyt asiakirjat, sekä Ruotsista tuodut että Senaatin kirjaajankonttorista (registratorskontoret) arkistoon luovutetut asiakirjat, tiliasiakirjat ja ratkaistujen asioiden aktit. Näitä asiakirjoja samoin kuin vanhempia maakirjoja, ei ilman vaivannäköä voitu löytää, kun niitä tarvittaisiin. Palkattavan henkilön pitäisi myös laatia inventaariluettelo ja ylläpitää sitä

Kaarlo Blomstedt, 'Uudenkaupungin ja Turun rauhansopimuksissa määrätyt asiakirjain luovutukset', Historiallinen Arkisto XXXII:12 (1924), s. 3-5, 14-23; M.V.Babič, Gosudarstvennye učreždenija XVIII veka: Komissii petrovskogo vremeni, Moskva 2003, s. 356-357; Eljas Orrman, 'Vanhan Suomen virastot ja muut arkistonmuodostajat sekä niiden arkistoaineistot', Vanhan Suomen arkistot, Arkistolaitoksen yleisluettelo VI, Porvoo 2012, s. 319. G. A. Spåre, Biografiska anteckningar om Kejserliga Regerings-Konseljens och Senatens för Finland ordförande och ledamöter samt embets- och tjenstemän under Åren 1809-1877, Helsingfors 1878 . Seuraavassa ei erikseen viitata tässä teoksessa esitettyihin henkilötietoihin. 
sekä pitää lainausrekisteriä. De Geerin ehdotuksen johdosta talousosasto päätti esittää keisari-suuriruhtinaalle, että Senaattiin saataisiin palkata arkistonhoitaja (archivarie) toistaiseksi ja niin pitkäksi aikaa kuin Senaatti piti sitä tarpeellisena. Kyseessä olisi ylimääräinen virka (å extra stat). ${ }^{22}$ Arkistonhoitajan toimenkuvan ajateltiin siis sisältävän sekä arkistotoimen ett asiakirjahallinnon hoitoon kuuluvia tehtäviä.

Tämän jälkeen kenraalikuvernööri Fabian Steinheil lähetti elokuun 10 päivänä talousosaston esityksen Pietariin Suomen asiain komitean puheenjohtajalle Knut von Troilille. Esityksessä keisarille toistettiin talousosaston istunnossa esiin tuodut asiat sekä todettiin, että arkistossa ei ollut yhtään virkamiestä lueteltuja tehtäviä suorittamaan sekä hoitamaan maan arvokkaimpia asiakirjoja. Tämä esitys käsiteltiin lokakuun 6 päivänä (ilmeisesti v.l.) rutiiniasiana Suomen asiain komiteassa. Sen jälkeen valtiosihteeri Robert Henrik Rehbinder esitteli talousosaston alistuksen keisarille marraskuun 13 päivänä v.l., eli marraskuun 25 päivänä u.l. ${ }^{23}$

Esittelyä varten Suomen asian komiteassa laadittu esittelynootti oli ranskankielinen. Siinä perusteltiin viran tarpeellisuus sekä todettiin sitten: "En conséquense le Sénat a cru devoir proposer, qu'il lui soit permis constituer ad interim et pour le tems que le besoin pourrait l'exiger un pareil Archiviste, dont les appointemets projetes à 500 roubles de argent seraient couches sur l'etat extraordinaire des depenses". Senaatti oli siis katsonut velvollisuudekseen esittää keisarille, että se saisi asettaa virkaan väliaikaisesti ja niin pitkäksi aikaa kuin tarve saattaisi sitä vaatia sellaisen arkistonhoitajan, jonka palkkaukseen tarvittavat varat merkittäisiin ylimääräiseen menosääntöön.

Esittelyn perusteella keisari allekirjoitti samalle päivälle päivätyn venäjänkielisen käskykirjeen, reskriptin. ${ }^{24}$ Sen virallisen ruotsinkielisen käännöksen todisti oikeaksi Suomen asiain komitean toimitussihteeri Lars Gabriel von Haartman, myöhemmin Senaatin talousosaston vaikutusvaltainen varapuheenjohtaja (vastasi pääministeriä). Tällä keisarillisella reskriptillä Senaattiin perustettiin arkistonhoitajan ylimääräinen virka, ${ }^{25}$ joskaan käskykirjeen venäläisessä tekstissä ei esiinny arkistonhoitajan (arhivarius) nimikettä; ruotsinkielisessä käännöksessä sen sijaan käytetään ilmaisua arkistonhoitaja (archivarie). Reskripti lähetettiin sitten kenraalikuvernöörille Senaatin talousosastolle toimitettavaksi.

Talousosaston yhteisistuntopöytäkirjat 1816 II, s. 1364r, Talousosaston reistraattorinkonttorin arkisto, Ca:15, Kansallisarkiston (KA) Helsingin toimipaikka. Valtiosihteerinviraston (VSV) akti 185 GG 16, VSV:n arkisto Ea:46; Suomen asiain komitean pöytäkirjat 6.10.1816, VSV:n arkisto Ca:10; Esittelynootti 13/25.11.1816, nro 363, Suomen asiain komitean esittelynootit 1816, VSV:n arkisto, Cc:8, KA:n Helsingin toimipaikka. Reskripti 13.11.1816, Keisarin käskykirjeet 1813-1816, s. 1032r-1034r, Talousosaston reistraattorinkonttorin arkisto, Ee:2, KA:n Helsingin toimipaikka. 
Hallitsijan käskykirje otettiin joulukuun 10 päivänä Senaatin talousosastossa käsiteltäväksi. Tällöin ilmeni asian käsittelyyn osallistuvien talousosaston jäsenten keskuudessa erimielisyyttä viran luonteesta ja hakuilmoituksen julkaisemismenettelystä. Ensimmäisenä kantansa esitti virkaiältään nuorin paikalla olleista talousosaston jäsenistä, esittelijäsihteeri Erik Wallenius (Wallensköld), joka oli tehnyt juristinuran molemmissa suomalaisissa hovioikeuksissa sekä lääninhallinnossa. Hän katsoi, että keisarillista käskykirjettä tuli tulkita siten, että arkistonhoitajan viran (archivarie-befattning) kohdalla oli kyse luonteeltaan tilapäisestä tehtävästä (som en commission). Sen vuoksi riittäisi, että hakuilmoitus kiinnitettäisiin kansliatoimituskunnan oveen hakuajan ollessa 30 päivää. Tätä näkemystä kannattivat juristi Claes Johan Sacklén (Edelsköld) sekä sotalaitoksen taloushallinnossa toiminut kamarineuvos Fredrik Lorentz Nyberg, jotka olivat paikalla olleista virkaiältään seuraavaksi nuorimmat.

Kollegineuvos Fredrik Wilhelm Ladau katsoi sen sijaan, että arkistonhoitajan tarve tulisi olemaan pitkäaikainen ja että tehtävä oli luonteeltaan kokopäiväinen. Tämän vuoksi hän esitti, että arkistonhoitajan viran hakuilmoitus pitäisi julkaista kolme kertaa Åbo Allmänna Tidningissä. Hän viittasi samalla talousosaston kannanottoon toukokuun 21 päivältä, jolloin talousosasto päätti hakumenettelystä julistaessaan haettavaksi neljä keisarillisella reskriptillä perustettua ylimääristä reviisorin virkaa. ${ }^{26}$ Ladaun näkemys tuli talousosaston päätökseksi, sillä siihen yhtyivät kenraalikuvernööri Steinheil, kreivi De Geer sekä eversti ja kanslianeuvos Nathanael Gerhard av Schultén. ${ }^{27}$ He olivat kaikki upseeritaustaisia, joskin af Schultén oli luonnontieteilijä ja entinen Karlbergin sota-akatemian professori. Hakuilmoitus, joka oli päivätty joulukuun 17 päivälle 1816, julkaistiin sitten saman kuun 28 päivänä edellä mainitussa sanomalehdessä hakuajan ollessa 30 päivää. ${ }^{28}$

Suhteellisen hyväpalkkaiseen tehtävään oli useita hakijoita. Muutamat heistä ilmoittivat kuitenkin, että ottavat toimen vastaan vain, mikäli saavat säilyttää entisen virkansa Senaatissa. Istunnossaan tammikuun 29 päivänä 1817 Senaatin talousosasto valitsi prokuraattorin toimituskunnan kopistin Johan Henrik Caloniuksen. Pöytäkirjan mukaan Senaatti näki hyväksi antaa Caloniukselle arkistonhoitajan virka: "fann Kejserliga Senaten godt, att, med afseende å Copisten Calonii witsordade flit och skicklight samt $i$ öfrigt ådaglagde wälförhållande, tillägga honom, Calonius den sökta archivarie beställningen, hvarå förordnande för honom således kommer att

Rauhala, Suomen keskushallinnon järjestäminen vuosina 1808-1817 II, Helsinki 1910, s. 110118.

27 Talousosaston yhteisistuntopöytäkirjat 1816 II, s. 2385 r-2387r, Talousosaston reistraattorinkonttorin arkisto, Ca: 15, KA:n Helsingin toimipaikka. - Vert. Talousosaston yhteisistuntopöytäkirjat $1816 \mathrm{I}$, s. $841 \mathrm{r}-841 \mathrm{v}$, Talousosaston reistraattorinkonttorin arkisto, Ca:14, KA:n Helsingin toimipaikka. 
utfärdas." ${ }^{29}$ Häntä ei siis nimitetty (utnämna) vakinaiseen virkaan eikä hän siten saanut valtakirjaa (fullmakt).

Vaikka Senaatin arkistonhoitaja oli keisarillisen käskykirjeen perusteella ylimääräinen virkamies, hän esiintyy vuodesta 1817 lähtien Senaatin palkkalistoissa, joihin ylimääräisiä virkamiehiä (extra[ordinarie] tjänstemän) ei merkitty. ${ }^{30}$ Kun Senaatin arkistonhoitajan virka seuraavan kerran täytettiin joulukuussa 1832, viran uusi haltija nimitettiin virkaan ja hänelle annettiin valtakirja, joten virka oli kiistatta muuttunut vakinaiseksi viraksi. ${ }^{31}$ Virka esiintyy painetussa valtiokalenterissa vuodesta 1818 lähtien. Suomen suuriruhtinaskunnalle annettiin arvojärjestys (rankijärjestys) 1826, jossa vakinaiset virat oli sijoitettu 14 arvoluokkaan. Siinä senaatin arkistonhoitaja oli sijoitettu 11. arvoluokkaan. ${ }^{32}$

On huomionarvoista, että arkistotoimen tehtäviä Senaatissa hoitamaan perustetun viran nimikkeeksi tuli arkistonhoitaja. Ruotsin valtionhallinnossa tämä virkanimike oli vielä 1800 -luvun ensimmäisellä vuosikymmenellä harvinainen. Sitä ei tavata valtakunnan kahdessa keskusarkistossa, Valtionarkistossa ja Kamariarkistossa. Arkistonhoitajan virka näyttää vuonna 1808 ollen vain kahdessa laitoksessa, Sotakollegiossa sekä Götan hovioikeudessa. Sen sijaan lähes kaikissa keskusvirastoissa, myös Kuninkaallisessa kansliassa, oli aktuaarin virka arkistotoimen ja asiakirjahallinnon tehtäviä varten; toisinaan aktuaarin tehtäviin oli yhdistetty kirjaajan tehtävät. ${ }^{33}$ Näyttääkin siltä, että nimikkeen arkistonhoitaja ilmestyminen Senaattiin on johtunut venäläisestä vaikutuksesta, sillä - kuten aiemmin on todettu - oli arkistonhoitaja (arhivarius)-nimike yleinen sekä Hallitsevassa senaatissa ja muissa keskushallinnon virastoissa samoin kuin myös kuvernementtihallinnossa.

Arkistonhoitaja-nimikkeen antaminen arkistotoimesta vastaavalle Senaatin virkamiehelle näyttäisi epäjohdonmukaiselta sen vuoksi, että Suomen johtavia hallituspiirejä edustanut ns. Armfeltin "liiga" pyrki määrätietoisesti torjumaan kaikenlaisen venäläisvaikutuksen suuriruhtinaskunnan hallinnosta ja mikäli mahdollista pitäytymään ruotsalaisessa hallintomallissa. Kun Vanha Suomi yhdistettiin suuriruhtinaskuntaan 1812, kaikki keskeiset virastot ja laitokset siellä lakkautettiin pian, ja tilalle perustettiin ruotsalaismalliset virastot. Siten Viipurin kuvernementinkanslia ja kameraalihovi saivat väistyä ja tilalle tuli läänihallitus. Ainakin kameraalihovissa oli toiminut arkistonhoitaja, ja kuvernementinhallituksessa oli 180o-luvun al-

Talousosaston yhteisistuntopöytäkirjat 1817 I, s. 141v-142r, Talousosaston reistraattorinkonttorin arkisto, Ca:16, KA:n Helsingin toimipaikka.

30 Senaatin palkkalistat 1816-1819, Senaatin tiliarkisto, ha:2, KA:n Helsingin toimipaikka.

31 Talousosaston yhteisistuntopöytäkirjat 1832 II, s. 1338r-v, Talousosaston reistraattorinkonttorin arkisto, Ca:76, KA:n Helsingin toimipaikka.

32 Finlands allmänna författningar V, Helsinfors 1831, s. 122-128.

33 Sveriges Krigs- och Civil-Calender 1808; Stockholms Stads-Calender 1808; Birger Steckzén, Krigskollegii historia II-III, Stockholm1937, s. 479. 
kuvuosina aktuaarin virka. ${ }^{34}$ Viipurin lääninhallitukseen jätettiin kyllä virkamies arkistotoimen tehtävien hoitamista varten, mutta nimitykseksi tuli ruotsalaisen terminologian mukaisesti aktuaari, ei Venäjällä yleinen arkistonhoitaja. Aktuaarin virka jäi kuitenkin Viipurissa lyhytaikaiseksi, sillä virka näyttää lakkautetun 1820-luvun puolivälissä, mutta 1829 tilalle ilmestyi arkistonhoitajan virka, aluksi ylimääräisenä virkana (å extra stat). ${ }^{35}$ Se että arkistonhoitajan virkanimike ei aluksi kelvannut Viipurin uuteen lääninhallitukseen osoittaa, että suomalaiset vierastivat tätä nimikettä ja että sen juurtuminen suuriruhtinaskunnan virkanimikkeistöön haluttiin estää. ${ }^{36}$ Siten on yllättävää, että Senaattiin ilmestyi arkistonhoitajan virka. Vaihtoehtona olisi tosin käytännössä ollut vain aktuaarin nimike, mutta Venäjällä aktuaarien toimenkuvassa kirjaamistehtävät olivat keskeisiä ja nimike oli siellä 1700luvun loppuun mennessä hävinnyt virastojen menosäännöistä. Myös kirjaajien ( $r e-$ gistrator) toimenkuva oli sellainen, että tämä virkanimike ei sopinut vanhemman (semi-current ja non current) asiakirja-aineiston hoidosta vastaavan virkamiehen nimikkeeksi. Jäljelle näyttäisi siten jääneen vain venäläisvaikutuksesta kielivä arkistonhoitajan (archivarie) nimike.

Kenraalikuvernöörinkansliaan oli autonomian alussa Viipurin län̈ninhallituksen tavoin perustettu aktuaarin virka, mutta uuden kenraalikuvernöörin A. A. Zakrevskin ryhdyttyä hoitamaan virkaansa 1824 muutettiin viran nimike arkistonhoitajaksi (archivarie). Kun Suomen asiain komitea Pietarissa lakkautettiin 1826 ja tilalle perustettiin Valtiosihteerinvirasto, myös sinne perustettiin arkistonhoitajan virka. ${ }^{37}$ Nämä nimikemuutokset ovat selvässä yhteydessä Zakrevskin tuloon kenraalikuvernööriksi. Ottaen huomioon aktuaarin virkanimikkeen toimenkuva Venäjällä sekä koko nimikkeen katoaminen sieltä 1800 -luvun alkuun mennessä

Polnoe sobranie zakonov Rossijskoj Imperii XXI, Sanktpeterburg 1830, nro 15141, 18 ja 25 \$\$; Raimo Viikki, 'Arkiven från Gamla Finland', Nordiske arkivstudier tilegnet landsarkivar dr.phil. Harald Jørgensen den 3. januar 1977, København 1977, s. 116; Yrjö Blomstedt, 'Ättartavlor för de på Finlands riddarhus icke inskrivna efter 1809 i finskt adligt, friherreligt eller grevligt stånd upphöjda ätterna', Suomen Sukututkimusseuran vuosikirja - Genealogiska Samfundets $i$ Finland årsskrift XXXVII, 1957-1959, Helsinki 1960, s. 77.

Keisarillisessa kirjeessä Viipurin läänin maaherralle 12.11.1816 luetellaan Vanhan Suomen kuvernementtihallinnosta lakkautettavat virastot ja virat sekä niiden tilalle lääninhallintoon perustettavat uudet virat. Niiden joukossa ei kuitenkaan esiinny aktuaarin virkaa, jollainen Viipurin lääninhallituksessa kuitenkin valtiokalenterin mukaan oli vuosina 1816-1824; kyseessä oli ilmeisesti ylimääräinen virka vaikka tätä ei todeta valtiokalentereissa. Samling af de till efterlefnad gällande Bref, Förklaringar och Föreskrifter hwilka af Hans Kejserl. Maj:t ..... blifwit utfärdade i Justitice-, Oeconomice- och Politice-Ärender I, ny upplaga, Helsingfors 1840, s. 118-120; Finlands statskalender 1816-1837.

Paaskoski, 'Vanhan Suomen hallintohistoria', s. 153-156; Yrjö Kaukiainen, 'Viipurin lääni palaa Suomeen - Suomi tulee Viipuriin', Autonomisen Suomen rajamaa, Viipurin läänin historia 5, Keuruu 2014, S. 21-23. Finlands statskalender 1816-1837; Finlands allmänna författningar V, s. 88. 
hallinnosta, ei ole yllättävää, että virkanimikkeen muutos toimeenpantiin kenraalikuvernöörin omassa virastossa samoin kuin Viipurin lääninhallituksessa. Uuden kenraalikuvernöörin pyrkimyksenä oli alusta alkaen lähentää suuriruhtinaskunnan hallintoa venäläiseen hallintoon, vaikka suuriruhtinaskunnan virastorakenteeseen ei tehtykään mitään muutoksia. - Zakrevskilla näyttää olleen kiinnostusta arkistoasioihin, sillä käydessään ensimmäisen kerran Senaatissa 1824 hän ei tutustunut ainoastaan Senaatin osastoihin, toimituskuntiin ja kamreerinkonttoreihin vaan myös arkistoon. ${ }^{38}$

Kuten edellä todettiin, Senaatin arkistonhoitaja oli suuriruhtinaskunnan arvojärjestyksen 11. arvoluokassa. Valtiosihteerinviraston arkistonhoitaja puolestaan oli sijoitettu 10. arvoluokkaan ja aktuaarit 13. arvoluokkaan. Kenraalikuvernöörinkanslian arkistonhoitaja ei sen sijaan esiinny arvojärjestyksessä.

Senaatin ensimmäinen arkistonhoitaja oli prokuraattori Mathias Caloniuksen veljenpoika ja samalla tämän kasvattipoika. Täytettäessä arkistonhoitajan virkaa Mathias Calonius ei enää ollut prokuraattorin virassa, sillä hän oli siirtynyt eläkkeelle jo helmikuussa 1816. Jää epäselväksi, missä määrin sukulaisuussuhde Mathias Caloniukseen on vaikuttanut talousosaston päätökseen. On kuitenkin otettava huomioon, että Senaatin palkkalistoihin sisällyttiin myös ne neljä revisiokonttorin ylimääräistä reviisoria (extra revisor), joiden virat oli samalla tavoin kuin arkistonhoitajan virka perustettu ylimääräisinä keväällä 1816 .

Edellä kuvatun prosessin tuloksena Senaatin talousosastoon perustettiin ylimääräinen arkistonhoitajan virka, joka prosessin loppuvaiheessa kuitenkin muuttui vakinaiseksi viraksi. Näyttää siltä, että suuriruhtinaskunnan postilaitoksen päällikkö ja senaatin jäsen Ladau kannanotollaan arkistonhoitajan viran hakumenettelyä käsiteltäessä merkittävällä tavalla vaikutti siihen, että virka käytännössä muuttui vakinaiseksi. Ladau kuului Venäjää vastaan 1788-179o käydyn sodan aikana innokkaimpiin Anjalan liiton miehiin, joutui sen vuoksi pakenemaan Venäjälle ja tuomittiin kuolemaan. Jo Suomen sodan aikana hän Venäjän palveluksessa ollen palasi takaisin kotimaahan ja nousi suuriruhtinaskunnan postilaitoksen johtoon. Hän nautti Venäjän hallituksen täyttä luottamusta ja oli venäläisen urkintajärjestelmän avainhenkilö maassamme. ${ }^{39}$ Voineekin sanoa, että hallinto-organisaation alatasolla venäläisen hallinnon suosikin Ladaun kannanotot olivat ratkaisevia, kun arkistotoimi Suomen senaatissa saatiin järjestettyä vakinaiselle kannalle vuosina 1816-1817, samalla tavalla kuin keskushallinnon ylimmällä tasolla hallituskonseljia perustettaessa venäläisen kenraalikuvernöörin M. B. Barclay de Tollyn kannanotot 1809

38 Rauhala, Keisarillinen Suomen senaatti 1809-1909 I, Helsinki 1915, s. 180.

39 Jukka-Pekka Pietiäinen, 'Gustaf Wilhelm Ladau', Kansallisbiografia V, Helsinki 2005, s. 653654 . 
käänteentekevällä tavalla johtivat maamme autonomisen aseman lujittumiseen pitemmässä aikaperspektiivissä. ${ }^{40}$

\section{Perustettiinko Senaattiin 1816-1817 arkistotoimen hoitamista varten itsenäinen organisaatioyksikkö?}

Keisarilliseen senaattiin oli siis 1817 perustettu arkistonhoitajan virka, jonka haltijan tehtäväkuvaan kuului sekä arkistotoimen että asiakirjahallinnon tehtäviä. Asiakirjahallinnon tehtävistä suurin osa kuului kuitenkin kirjaajille, joita oli sekä talousosastossa että oikeusosastossa. Arkistonhoitajan viran perustamisella haluttiin kuitenkin järjestää Senaattiin, Senaatin yleiseen arkistoon, koottujen vanhempien asiakirja-aineistojen hoito. Tämän viranhaltijan tehtäviin kuului myös näihin aineistoihin samoin kuin senaatissa loppuun käsitellyissä asioissa kertyneisiin asiakirjoihin liittyvä tietopalvelu. Virka oli käynyt välttämättömäksi sen vuoksi, että Suomen suuriruhtinaskuntaan oli muodostettu Venäjän keisarikunnan hallinnosta erillään toimiva keskushallinto-organisaatio.

Samanlainen kuin Suomessa tilanne oli myös Norjassa, jonka Tanska 1814 Kielin rauhassa joutui luovuttamaan Ruotsille siten, että molemmat kuningaskunnat muodostivat saman hallitsijan alaisen unionin. Norjan hallituksen yhteyteen perustettiin 1817 Valtionarkisto, Riksarkivet. Tätä nimitystä oli kuitenkin jo 1782 käytetty tanskalaishallinnon aikaisista arkistoaineistoista. Valtionarkisto sijoitettiin Norjassa finanssiministeriöön ja sen tehtäväkenttä tuli painottuman asiakirjahallintoon. Arkisto oli aluksi heikosti resursoitu, sillä Valtionarkiston johto oli pitkään finanssiministeriön eri virkamiesten osa-aikaisena tehtävänä. ${ }^{41}$

Millaiset olivat ne organisatoriset puitteet, joissa Suomen Senaatin arkistonhoitajan toiminta tapahtui? Mitään yksiselitteistä vastausta tähän ei ole, mutta tiettyjä päätelmiä on kuitenkin mahdollista tehdä.

Hallituskonseljin (Senaatin) organisaatiorakenne määrättiin sen ohjesäännössä elokuun 18 päivältä 1809 . Siinä Senaatin organisaatio esitettiin hyvin pelkistettynä, sillä ohjesäännössä lueteltiin ainoastaan molemmat osastot, talous- ja oikeusosasto, sekä toimituskunnat. Sekä valtiokalentereissa että Senaatin palkkauslistoissa esiintyvät organisaatioyksikköinä aina 1840-luvulle saakka ainoastaan osastot ja toimituskunnat, poikkeuksena kuitenkin kamaritoimituskunnan yhteydessä toiminut revisiokonttori, joka pian itsenäistyi itsenäiseksi virastoksi. Hallituskonseljiin syntyi

$40 \quad$ Jussila, Suomen suuriruhtinaskunta, s. 101-107.

41 Knut Johannessen, Ole Kolsrud, Dag Mangset, Handbok for Riksarkivet, Oslo 1992, s. 301; Eljas Orrman, 'The Archives and the Archival Profession in the Nordic Countries', Archives, archivistes, achivistique, dans l'Europe du Nord-Ouest du Moyen Âge à nos jours. Entre gouvernance et mémoire, Lille 2006, s. 232. 
kuitenkin pian tosiasiallisia yksiköitä, kun muutaman johtavan viran tehtäväkenttä määriteltiin virkaa koskevassa johtosäännössä. Tällä tavoin syntyivät jo vuoden 1810 tienoilla eräiden toimituskuntien yhteyteen kamreerinkonttorit (valtiovarainkonttori, kamarikonttori ja sotilaskonttori). Lisäksi valtiovaraintoimituskunta toimi vuosikymmenen ajan kahteen osastoon jakautuneena. Merkkinä tällaisesta itsenäisestä asemasta toimituskuntien piirissä oli, että nämä yksiköt pitivät omia diaareja ja niihin liittyviä muita asiakirjasarjoja. Prokuraattorin alaisista virkamiehistä muodostettiin 1810 -luvulla erillinen prokuraattorin toimituskunta. ${ }^{42}$ Senaatin talousosaston kansliatoimituskunnassa diarioitiin autonomian alkuaikoina valtaosa osaston kirjeenvaihdosta ja hoidettiin talousosaston aktinmuodostus. Kirjaajat muodostivat erillisen toimintayksikön, jota kutsuttiin kirjaajankonttoriksi (registratorskontoret).

Senaatin ohjesäännössä yleisen esittelijäsihteerin tehtävät liittyivät pääasiassa plenumia sekä talousosaston toimituskuntien yhteisiä kokouksia koskeviin asioihin. Hänen vastuualueeseensa kuuluivat myös Senaatin arkistoihin (arkiverne) liittyvät asiat. Hänen alaisuudessaan toimivat senaatin kielenkääntäjät ja vuodesta 1817 lähtien myös arkistonhoitaja. Jo aikaisemmin arkistotehtäviä varten (vid arkivet) oli vahtimestari. Yleisen esittelijäsihteerin alainen henkilökunta muodosti erillisen yksikön, jossa pidettiin omia diaareja vuodesta 1811 lähtien; sen nimeksi vakiintui Senaatin yleinen kanslia. ${ }^{43}$

Arkistonhoitajan viran perustamisprosessiin liittyvissä asiakirjoissa käytettiin ilmaisuja, jotka antavat ristiriitaisen kuvan siitä, mitä ilmaisulla "Suomen yleinen arkisto", jota myös kutsuttiin "Keisarillisen senaatin yleiseksi arkistoksi" (ruotsiksi: Finlands allmänna arkiv, venäjäksi: obščij Finljandskij Arhiv) ymmärrettiin. Keisarillisessa käskykirjeessä todetaan talousosaston pitävän tarpeellisena saada Suomen yleiseen arkistoon arkistonhoitotehtäviä hoitava virkamies, "....neobhodimym imet' činovnika pri obščem Finljandskom Arhive...". Ilmaisussa käytetään prepositiota "pri", jolla mm. ilmaistaan "johonkin laitokseen, virastoon kuulumista". Käskykirjeen hyvin vapaassa virallisessa ruotsinnoksessa sama asia kuitenkin ilmaistaan siten, että Senaatti pitää tarpeellisena henkilöä hoitamaan ja pitämään järjestyksessä Suomen yleisessä arkistossa säilytettyjä asiakirjoja, "behofvet af en Person, som borde vårda och i ordning ställa .... alla uti Finlands allmänna Archiv förvarade, så väl .... [som dit] aflefvererade Handlingar, ....... Nämä ilmaisut voidaan tulkita siten, että Suomen yleisellä arkistolla ymmärrettiin joko organisatorista yksikköä tai arkistotiloja, joissa asiakirjoja säilytettiin. Kun ottaa huomioon Senaatin talousosaston organisatorisen rakenteen luonteen, ei arkistonhoitajan ja häntä avustavan vahtimestarin toiminta ole kuitenkaan 180o-luvun alkupuolella voinut joh- 
taa sellaisen toimijan muodostumiseen Senaattiin, joka olisi täyttänyt varsinaiselle organisaatioyksikölle asetettavat kriteerit. Arkistotehtävien hoito ei vielä pitkään aikaan muodostunut sellaiseksi, että sillä olisi ollut omaa kirjeenvaihtoa muiden toimijoiden kanssa. Voitaneen kuitenkin katsoa, että Senaatin yleisen esittelijäsihteerin johtamaan yksikköön syntyi arkistonhoitajan viran saamisen myötä selvärajainen Senaatin arkistotiloissa säilytetyn vanhemman (semi-current ja non current) asiakirja-aineiston arkistonhoitoa ja tähän aineistoon liittyvää tietopalvelua hoitava toiminto.

Arkistonhoitajan viran saaminen Senaattiin ei vielä merkinnyt sitä, että varsinaiset arkistonhoidolliset tehtävät olisivat nousseet keskeiseen asemaan arkistonhoitajan tehtäväkentässä. Tämän viranhaltijan tehtävät painottuivat Senaatin virkatoimintaa palvelevien tietopalvelutehtävien hoitamiseen, eikä ensimmäisillä arkistonhoitajilla myöskään ollut koulutuksensa perusteella edellytyksiä ymmärtää hoidossaan olevien asiakirjojen osalta muita kuin viranomaistoiminnan ajankohtaisia tarpeita. Siten vanhimmat Ruotsista Haminan rauhansopimuksen perusteella Suomeen siirretyt asiakirja-aineistot, jotka myöhempi historiantutkimus on katsonut kaikkein arvokkaimmiksi Senaatin vastuulle luovutetuista aineistoista, jäivät Senaatin uudessa 1820 -luvun alussa valmistuneessa rakennuksessa Helsingissä yli pariksi vuosikymmeneksi hoitoa ja valvontaa vaille rakennuksen ullakolle. Näiden asiakirjojen kohtalo ei kuitenkaan ollut mitenkään poikkeuksellinen. Euroopan valtioissa ei nimittäin ollut mitenkään harvinaista, että rauhansopimusten perusteella saadut ja suurin kustannuksin erotetut ja kuljetetut arkistoaineistot, sen jälkeen kun ne oli saatu vastaanotetuiksi, jäivät vaille hoitoa ja valvontaa ja joutivat sen vuoksi epäjärjestykseen. ${ }^{44}$ 